DOI https://doi.org/10.30525/978-9934-26-114-5-33

\title{
ТЕОРЕТИКО-МЕТОДОЛОГІЧНІ АСПЕКТИ ОРГАНІЗАЦЇ̈ САМОСТІЙНОЇ РОБОТИ МАЙБУТНІХ МАГІСТРІВ ПСИХОЛОГІї
}

\author{
Бужинська С. М. \\ кандидат психологічних наук, доцент, \\ доцент кафедри педагогіки, психології, початкової освіти та \\ освітнього менеджменту \\ Комунальний заклад «Харківська гуманітарно-педагогічна академія» \\ Харківської обласної ради \\ Толмачова I. М. \\ кандидат педагогічних наук, доиент, \\ професор кафедри педагогіки, психології, початкової освіти та \\ освітнього менеджменту \\ Комунальний заклад "Харківська гуманітарно-педагогічна академія» \\ Харківської обласної ради \\ м. Харків, Украӥна
}

В умовах сьогодення принципово змінилися світоглядні орієнтири розвитку української системи вищої освіти, яка функціонує в контексті європейської інтеграції. Дані процеси вплинули на інтенсивну розробку всіх складників професійно-педагогічної підготовки майбутніх магістрів психології, зокрема, самостійної роботи, задля системної імплементації європейських освітніх цінностей та одночасного збереження та розвитку кращих надбань вітчизняних науковців в означеному напрямку.

Мета роботи - схарактеризувати теоретико-методичні аспекти організації самостійної роботи майбутніх магістрів психології.

Науковий дискурс щодо самостійної роботи студента суттєво активізувався останнім часом. Аналіз наукових розвідок свідчить про багатомірність і різноплановість поняття «самостійна робота студента». Дослідники розглядають його з різних позицій: як різновид навчальних занять (П. Підласистий, М. Скаткін, І. Ільясов), як метод пізнавальної діяльності (А. Алексюк, Б. Ссипов), вид індивідуальної та групової пізнавальної діяльності студентів (О. Малихін); як засіб творчого розвитку особистості майбутнього фахівця (В. Александрова, К. Білоконь, А. Савченко), як передумову становлення майбутнього фахівця (М. Шепель) тощо. Таке розмаїття підходів та трактувань, 
певним чином, ускладнює теоретичні пошуки та практичні розробки в означеному напрямку.

Н. Бойко пише: «Самостійна робота - це складне багатомірне педагогічне явище, яке включає систему взаємопоєднаних структурних i функціональних компонентів, що утворюють цілісну єдність, підпорядковану цілям виховання, освіти і розвитку в умовах ії опосередкованого управління та самоуправління» [1]. Ми доєднуємося до трактування поняття «самостійна робота студента», запропонованого О. Білоус: «Самостійну роботу студентів розглядаємо як пізнавальну діяльність, виконувану студентом самостійно або під керівництвом викладача, із використанням заданої програми або інструкції, i спрямовану на виконання завдань (або вирішення завдань), 3 урахуванням особистих потреб і інтересів, психологічних особливостей студентів» [3].

Дидактичними цілями самостійної роботи здобувачів вищої освіти $€$ : навчити їх самостійно здобувати знання з різних джерел, формувати навички й уміння, необхідні майбутнім фахівцям; підвищити відповідальність за свою професійну підготовку, формування особистісних і професійно значущих якостей; розвивати самостійність у плануванні, організації й виконанні своєї майбутньої професійної діяльності; формувати у студентів професійне мислення на основі виконанням індивідуалізованих творчих завдань із курсів і навчальних дисциплін [2].

Самостійну роботу студента в сучасних дослідженнях аналізують як багатофункціональне та міждисциплінарне явище педагогічної дійсності, у якому виділяють такі основні функції [3]: пізнавальна функція визначається засвоєнням студентом систематизованих знань 3 освітнього компоненту; самоосвітня функція - забезпечує формування вмінь i навичок студентів, самостійного їхнього відновлення та творчого застосування; прогностична функція зумовлює набуття студентами вміння вчасно передбачати й оцінювати як можливий результат, так і саме виконання завдання; коригувальна функція зумовлює вміння вчасно коректувати свою діяльність; виховна функція - формування самостійності студента як риси характеру.

Серед дидактичних та організаційно-педагогічних умов організації самостійної роботи відзначають: забезпечення систематичності, впорядкованості, диференціації, професійної орієнтованості та свідомого характеру самостійної роботи; інтеграцію в усі форми навчального процесу; функціональну підпорядкованість, структурованість змісту, часову доцільність; оптимальну конвергенцію аудиторної й самостійної позааудиторної роботи тощо. 
В ході організації самостійної роботи студента необхідно орієнтуватися на нормативні документи ЗВО, зокрема, у Харківській гуманітарно-педагогічній академії це: «Положення про організацію освітнього процесу у Комунальному закладі «Харківська гуманітарнопедагогічна академія» Харківської обласної ради та іiі структурних підрозділах», «Положення про дистанційне навчання», «Порядку оцінювання здобутих компетентностей здобувачів вищої освіти відповідно до вимог кредитної трансферно-накопичувальної системи організації освітнього процесу», «Положення про робочу навчальну програму дисципліни та методичні рекомендації до ії розробки».

Сучасні та майбутні роботодавці зацікавлені у фахівцеві, який: здатен до пошуку, оброблення і аналізу інформації з різних джерел із використанням IКТ; вміє генерувати нові ідеї (креативність) та володіє навчиками критичного мислення (сформованими у процесі навчання); застосовує набуті знання у практичних ситуаціях; вміє виявляти, ставити та вирішувати проблеми особистісного i професійного розвитку, тобто застосовує знання, отримані в процесі навчання; вміє здобувати нові знання, тобто здатний до самоосвіти.

В процесі самостійної роботи майбутніх магістрів психології важливо комплексно реалізувати сучасні умови й вимоги до іiі організації у відповідності до студентоцентрованого та компетентнісного підходів та системно забезпечити їхнє професійне орієнтування на психологічний супровід та викладацьку діяльність.

Організація самостійної роботи майбутніх магістрів психології вимагає й врахування сучасних тенденцій, зокрема: відповідність основним вимогам, що відображено у освітньо-професійній програмі Психологія для другого (магістерського) рівня вищої освіти; підвищення питомої ваги самостійної роботи в загальному обсязі навчального часу, що детермінує іiі розгляд як провідної форми навчання; необхідність свідомого дотримання норм академічної доброчесності; врахування суті та специфіки дистанційного та змішаного навчання в умовах пандемії COVID-19 тощо.

Ефективність самостійної роботи студентів відображається у таких результатах [4]: студент проявляє самостійне, творче мислення, уміє користуватися понятійним апаратом, синтезує знання 3 ряду тем, вільно справляється 3 практичними завданнями; студент повністю засвоює програмний матеріал; студент уміє застосовувати основні положення, принципи теорії при аналізі сучасної дійсності; студент глибоко вивчив першоджерела; студент оволодів навичками самостійної роботи (уміє здійснювати пошук необхідної літератури, її вивчати та вести записи); здатен до самоосвіти. 
Висновки. Отже, виходячи 3 вищеозначеного можемо зробити наступні висновки:

1. Самостійна робота $є$ організованою викладачем активною діяльністю студента, направленою на виконання поставленої дидактичної мети, але здійснюється без посередньої його участі.

2. Самостійна робота студентів має грунтуватися на певних концептуальних засадах: наукових підходаx, відповідному змісті, формах, методах і засобах навчальної діяльності.

3. Самостійна робота відіграє важливу роль у комплексному формуванні інтегральної, загальних та професійних компетентностей здобувачів вищої освіти, що відповідає світовим та вітчизняним стандартам та регіональному запиту щодо особистості сучасного магістра психології.

Подальшої розробки потребують організаційно-методичні аспекти забезпечення самостійної роботи майбутніх магістрів психології у процесі дистанційної освіти.

\section{Література:}

1. Бойко Н.І. Організація самостійної роботи студентів вищих навчальних закладів в умовах застосування інформаційно-комунікаційних технологій: автореф. дис. на здобуття наук. ступеня канд. пед. наук: 13.00.04. Київ, 2008. 23 c. http://enpuir.npu.edu.ua/bitstream/handle/ 123456789/494/Bojko.pdf?sequence=3 (дата звернення: 07.07.2021).

2. Організація самостійної роботи студентів 3 педагогіки : [посібник] / В.І. Свдокимов, Т. П. Агапова, І. В. Гавриш, В. В. Луценко. Харків: ХДПУ імені Г.С. Сковороди, 2000. - 160 с.

3. Теорія і практика організації самостійної роботи студентів вищих навчальних закладів: Монографія. Кол. авторів / ред. проф. О. А. Коновала. Кривий Ріг : Книжкове видавництво Киреєвського, 2012. $380 \mathrm{c}$.

4. Хоменко-Семенова Л.О. Організація самостійної позааудиторної роботи студентів технічних спеціальностей (на прикладі вивчення дисципліни «Психологія ділового спілкування»). Вісник Національного авіаиійного університету. Педагогіка. Психологія. № 1 (8). 2016. https://er.nau.edu.ua/handle/NAU/37522 (дата звернення: 09.07.2021). 